\section{Unusual location of mandibular osteoid osteoma: A case report}

\section{Mandibular osteoid osteomanın nadir lokalizasyonu: Bir olgu sunumu}

\section{Assist. Prof. Saadettin Kayıpmaz}

Karadeniz Technical University, Faculty of Dentistry Department of Oral and Maxillofacial Radiology, Trabzon

\section{Dr. Pınar Gökçen Yücesan}

Karadeniz Technical University, Faculty of Dentistry Department of Oral and Maxillofacial Radiology, Trabzon

\section{Assist. Prof. Celal Candırlı}

Karadeniz Technical University, Faculty Of Dentistry Department of Oral and Maxillofacial Surgery, Trabzon

\section{Assist. Prof. Ömer Said Sezgin}

Karadeniz Technical University, Faculty Of Dentistry Department of Oral and Maxillofacial Radiology, Trabzon

\section{Assist. Prof. Sevdegül Mungan}

Karadeniz Technical University, Faculty Of Medicine Department of Pathology, Trabzon

Received: 27 Mart 2017

Accepted: 11 April 2017

doi: 10.5505/yeditepe.2017.70299

\section{Corresponding author:}

Assist. Prof. Saadettin Kayıpmaz

Karadeniz Technical University, Faculty of Dentistry Department of Oral and Maxillofacial Radiology 61080 Trabzon - Türkiye

Tel: 05385471295

E-mail:skayipmaz@yahoo.com

\section{SUMMARY}

Osteoid osteoma is a benign nonodontogenic tumor that seldom occurs in the jaws. Severe pain that relieves with NSAIs is characteristic feature of this tumor. A 20-year-old male patient was referred to our clinic with the chief complaint of severe pain in right mandibular posterior region. On panoramic radiograph a radiolucent lesion with sclerotic border surrounding the folicle of partially embedded \#48 was observed. \#48 was extracted and the lesion was enucleated under local anesthesia. Pathologic examination results were consistent with osteoid osteoma. In this case, it is aimed to present a case of osteoid osteoma in $\mathrm{CBCT}$ images with unusual location and radiologic features that radiologists should pay attention to for correct diagnosis

Key words: Bone neoplasms, bone tissue, osteoid osteoma

\section{ÖZET}

Osteoid osteoma çenelerde nadir görülen benign nonodontojenik bir tümördür. NSAìnflamatuarlar ile hafifleyen şiddetli ağrı bu tümörün karakteristik özelliğidir. 20 yaşında erkek hasta sağ alt arka bölgede şiddetli ağrı şikayetiyle kliniğimize başvurdu. Panoramik radyografide yarı gömülü \#48' in folikülünü çevreleyen, sklerotik sınırlı radyolusent bir lezyon izlendi. Lokal anestezi altında \#48 çekimi yapıldı ve lezyon enükleasyonu gerçekleştirildi. Patolojik inceleme sonucu osteoid osteoma ile uyumludur. Bu olgu sunumunda radyologları CBCT görüntüleri üzerinde doğru diagnoza yönelten nadir lokasyon ve radyografik özelliğiyle bir osteoid osteoma olgusu sunulması amaçlanmıştır.

Anahtar Kelimeler: Kemik neoplazmları, kemik dokusu, osteoid osteoma

\section{INTRODUCTION}

Osteoid Osteoma (OO) is a benign lesion rarely seen at maxilla and mandible. ${ }^{1}$ It is mostly observed in femur and tibia. ${ }^{2}$ Clinically $\mathrm{OO}$ is more prevalent in young males. The characteristic property of the lesion is that it causes intense pain in the bone tissue and this pain is relieved with use of anti-inflammatory drugs. There may be edema and tenderness at the surrounding soft tissue. Although it is mostly localized to cortices of tibia and femur, if it is encountered in the mandible it is radiographically observed as a lesion developed in the body of the mandible. It has appearance of a mixed lesion with sclerotic borders. $\mathrm{OO}$ can also be detected around temporomandibular joint..$^{3.5} \mathrm{It}$ can lead to cortical thickening and expansion by stimulating sclerotic bone reaction and periosteal bone formation. Differential diagnosis of OO should include other lesions showing calcification. These are sclerosing osteitis, cemento-ossifying fibroma, benign cementoblastoma and cemental dysplasia. ${ }^{1}$ Discrimination from particularly osteoblastoma is also important. $\mathrm{OO}$ is distinguished from osteoblastoma by its size being smaller than $1.5-2 \mathrm{~cm}$ and not showing tendency for growth. ${ }^{6}$ Normally, osteoblastoma does not break through the cortical border to invade 
soft tissues and it causes sclerotic bone reaction at the periphery. ${ }^{1}$ A study examining osteoblastoma and osteoid osteoma has shown that the two lesions differed for their distinguishing properties, which are the lesion size and the size of radio-opaque foci, and for this reason, has suggested that OO was an early stage of osteoblastoma. ${ }^{7}$ In this paper, we aimed to present a case with osteoid osteoma with its clinical and radiographic properties; in which the lesion was localized to a rare site: neighborhood of the follicle of mandibular third molar tooth.

\section{CASE REPORT}

19 years old male patient presented to our clinic with complaint of pain at the right side of the mandible. It was learned that the intense and prolonged pain which started a couple of weeks ago subsided with use of non-steroid anti-inflammatory drugs. He had no other systemic disease according to his medical history. During intraoral examination, third molar tooth at lower right molar region was observed as impacted. There was not any pathology observed in the soft tissue. Radiographic examination revealed follicular expansion superior to mandibular canal, distal to the impacted tooth 48, and a mixed lesion with sclerotic borders posterior to this (Figure 1).

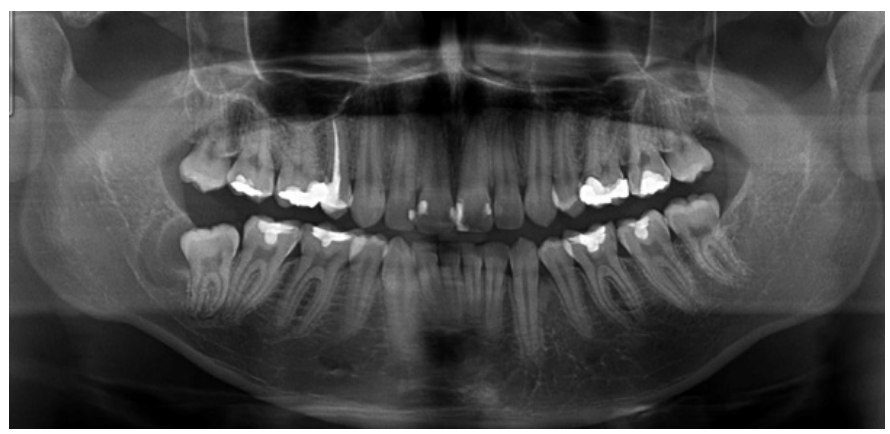

Figure 1. Follicular expansion of the impacted third molar and a mixed lesion with sclerotic borders on the panoramic image.

In cone beam CT examination, there was a mixed lesion approximately $18 \times 7 \times 14 \mathrm{~mm}$ in size, posterior to the hyperplastic follicle of the third molar tooth and surrounding the follicle; it had sclerotic borders and internal calcification, it caused cortical thinning both in buccal and lingual directions and decortication in mandibular canal (Figure 2, 3).

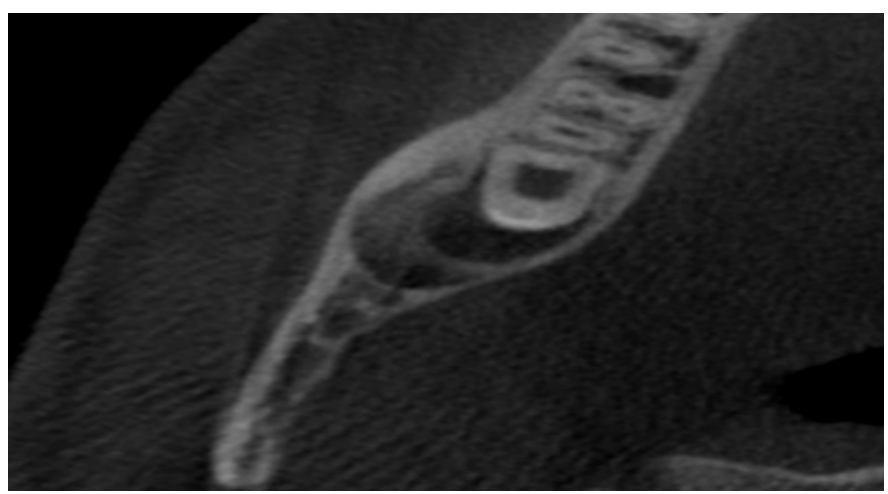

Figure 2. Mixed lesion with the posterior border of the neighboring follicle and the lesion causing thinning in vestibular and lingual cortex on the axial CBCT image.

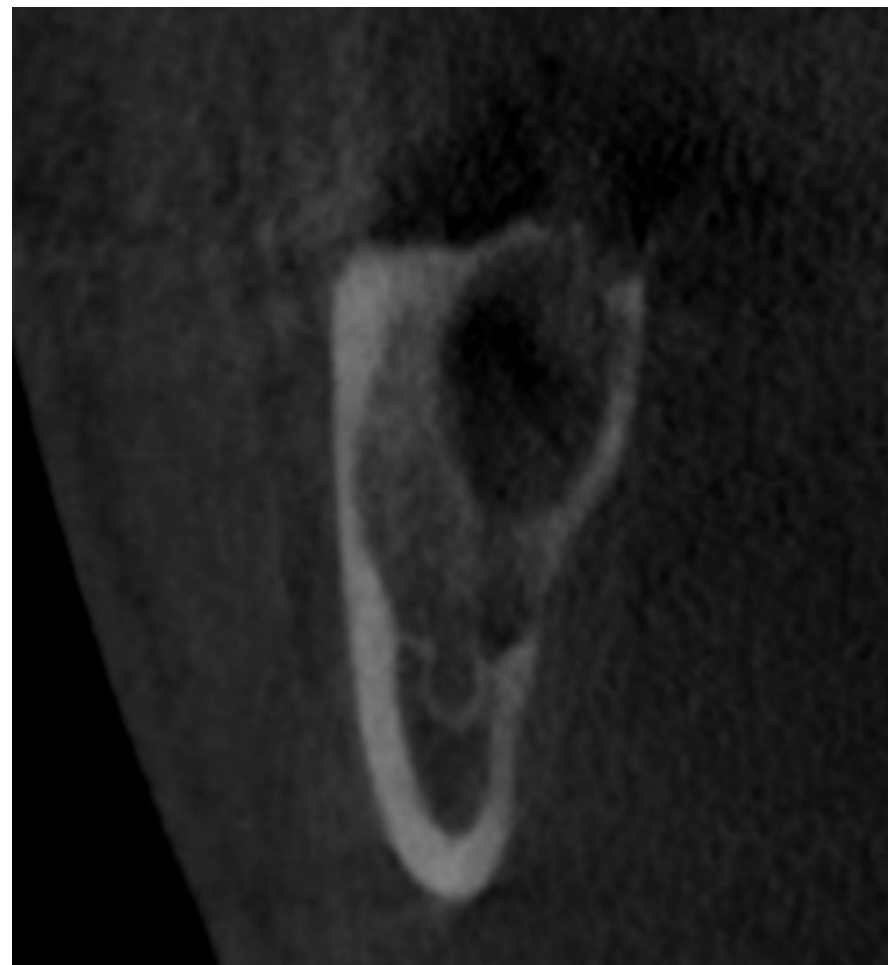

Figure 3. Epicenter of the lesion is above mandibular canal on the frontal image. There was no perforation at the cortex, however there was decortication at the mandibular canal.

With an initial diagnosis of OO, excision was planned. The lesion was totally excised with removal of third molar tooth. The lesion was diagnosed as osteoid osteoma in histopathological examination (Figure 4). Fibrohyalinized connective tissue filling between neoplastic osteoid structures were observed on histopathologic sections. The patient is being followed up for recurrence.

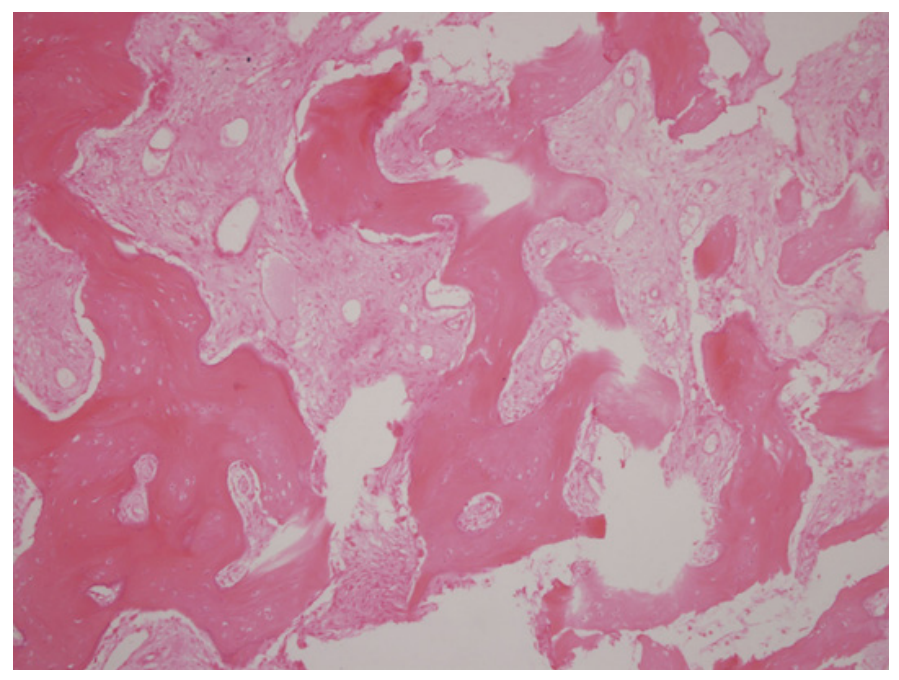

Figure 4. Histopathologic appearance of the lesion. HE X 200; Fibrohyalinized connective tissue filling between neoplastic osteoid structures.

\section{DISCUSSION}

$\mathrm{OO}$ is one of the mandibular lesions distinguished from other sclerotic lesions by its prevalence, localization, size, clinical symptoms, internal structure and effect on the surrounding tissues.

Studies related to frequency of this lesion report $\mathrm{OO}$ as a bone lesion that is most frequently localized long bones, developing in individuals aged between $5-20$ years old. ${ }^{6}$ 
In Turkish population, it was reported that OO lesion is observed in the mandible in the rate of $2 \%{ }^{2}$ The lesion described in our case was detected in an 18 years old male patient.

In terms of the localization, apart from the long bones, body of the mandible is also a typical site for development of the lesion. ${ }^{1}$ Otherwise the lesion can be observed at condylar region or eminence..$^{3.5}$ When at condylar region, it can cause limitation of mouth opening. ${ }^{4,8}$ Additionally, there has been a case of $\mathrm{OO}$ related with the apex of mandibular second premolar and first molar teeth. ${ }^{9}$ In our case, the lesion was localized to neighborhood of the tooth follicle superior to mandibular canal, distal to third molar tooth at right lower mandible as a unifocal lesion. As for the size, OO is generally accepted to be about $1 \mathrm{~cm}$ in diameter. ${ }^{1}$ The lesion size may show growth in time. ${ }^{8}$ In a study examining osteoblastoma histopathologically, results were compared to many $\mathrm{OO}$ cases reported before, and it was noted that $\mathrm{OO}$ lesions showed variation for lesion size and size of the radio-opaque foci, which are the known distinguishing criteria. It was proposed that $\mathrm{OO}$ could be regarded as an early stage of osteoblastoma. ${ }^{7}$ In our case, the lesion was in the shape of a crescent, coalesced with the posterior border of the neighboring follicle, and its size was similar to other reported sizes for OO before.

Considering evaluation of symptoms, in a study examining $\mathrm{OO}$ developing at whole body, the most common clinical symptom was reported as pain. ${ }^{2}$ The pain caused by $\mathrm{OO}$ at the mandible relieves with salicylates and anti-inflammatory drugs. ${ }^{1,6,8}$ Rahsepar et al. ${ }^{8}$ reported a case who refused treatment after the first diagnosis of OO detected at subcondylar region; pain and swelling increased after one year, and maximum mouth opening was limited even further. Another study suggested a relationship between patient age and nidus mineralization and pain duration..$^{10}$ In our case, patient particularly had prolonged intermittent pain complaint. Clinical evaluation suggested that the pain was not related with the impacted third molar tooth. In patient's history, his pain relieved with anti-inflammatory drug use, which was evaluated as a feature in support of OO diagnosis clinically. OO's internal structure and effect on the surrounding structures have spesific features. When in the mandible, it has been described as unifocal radiolucent lesion with prominent borders containing radio-opaque foci inside. Sclerotic borders and sclerotic bone reaction are the typical features of 0O. ${ }^{1}$ The lesion can cause cortical perforation at advanced stages. ${ }^{8}$ Accepted criteria for differentiation of $\mathrm{OO}$ from osteoblastoma are that $\mathrm{OO}$ lesions are smaller in size and cause sclerotic bone reaction; ${ }^{1}$ therefore our case was evaluated in this respect. There was no sclerotic bone reaction or periosteal reaction around the lesion. Moreover, the lesion caused thinning in vestibular and lingual cortex. There was no perforation observed at cortex; however there was decortication at the superior cortex of mandibular canal. It was a unilocular lesion and a radiolucent area was distinguished close to central part of internal calcification.

Treatment of OO lesions is total excision. In our case, after the third molar was extracted, the bone structure distal to the created cavity and the follicular space also had a curatable feature. This tissue was removed completely with a curette while conserving inferior alveolar nerve, and the patient was taken into follow up.

In conclusion, in our case who had history of prolonged intermittent type of pain and typical features of $\mathrm{OO}$ that we detected, localization of the lesion was interestingly surrounding the follicle of the impacted third molar tooth. It should be distinguished from other sclerotic lesions with its clinical and radiographical features in order to determine effective treatment approaches; and it should be followed up for recurrence.

\section{REFERENCES}

1.White SC, Pharoah MJ. Oral radiology principles and interpretation. 6th ed., St. Louis, Mosby; 2009.

2.Yalcinkaya U, Doganavsargil B, Sezak M, Kececi B, Argin $\mathrm{M}$, Basdemir G, Oztop F. Clinical and morphological characteristics of osteoid osteoma and osteoblastoma: a retrospective single-center analysis of 204 patients. Ann Diagn Pathol 2014; 18: 319-325.

3.do Egito Vasconcelos BC, Porto GG, Bessa-Nogueira RV. Rare Benign Tumors of the Mandibular Condyle: Report of 2 Cases and Literature Review. J Oral Maxillofac Surg 2007; 65: 1830-1835.

4. Tochihara $S$, Sato $T$, Yamamoto $H$, Asada $K$, Ishibashi $K$. Osteoid osteoma in mandibular condyle. Int $\mathrm{J}$ Oral Maxillofac Surg 2001; 30: 455-457.

5. Yang C, Qui WL. Osteoid osteoma of the eminence of the temporomandibular joint. British $\mathrm{J}$ Oral and Maxillofac Surg 2001; 39: 404-406.

6.Boscainos PJ, Cousins GR, Kulshreshtha R, Oliver TB, Papagelopoulos PJ. Osteoid osteoma. Orthopedics 2013; 1: 792-800.

7.Jones AC, Prihoda TJ, Kacher JE, Odingo NA, Freedman PD. Osteoblastoma of the maxilla and mandible: a report of 24 cases, review of the literature, and discussion of its relationship to osteoid osteoma of the jaws. Oral Surg Oral Med Oral Pathol Oral Radiol Endod 2006; 102: 639-650.

8.Rahsepar B, Nikgoo A, Fatemitabar SA. Osteoid Osteoma of Subcondylar Region. Case Report and Review of the Literature. J Oral Maxillofac Surg 2009; 67: 888-893. 9.Mohammed I, Jannan NA, Elrmali A. Osteoid osteoma associated with the teeth: unusual presentation. Int $\mathrm{J}$ 
Oral Maxillofac Surg 2013; 42: 298-302.

10. Touraine S, Emerich L, Bisseret D, Genah I, Parlier-Cuau C, Hamze B, Petrover D, Laredo JD, Bousson V. Is pain duration associated with morphologic changes of osteoid osteomas at CT? Radiology 2014; 271: 795-804. 